\title{
PENEGAKAN HUKUM TERHADAP NOTARIS YANG MEMPROMOSIKAN DIRI MELALUI MEDIA SOSIAL
}

\author{
Riyan Saputra \\ (Mahasiswa Program S1 Fakultas Hukum Universitas Tarumanagara) \\ (E-mail: riyansap03@gmail.com)
}

Gunawan Djajaputra

(Corresponding Author)

(Dosen Hukum Agraria Fakultas Hukum Universitas Tarumanagara, Meraih Sarjana Hukum dari Fakultas Hukum Universitas Indonesia, Magister Hukum dari Fakultas Hukum Universitas Indonesia, Doktor Hukum dari Fakultas Hukum Universitas Indonesia)

(E-mail: gunawand@fh.untar.ac.id)

\begin{abstract}
Notary is a carrier of office or ordinary we call the general officer appointed by the state and also work for the service of the public interest, in carrying out its duties a Notary must adhere to the rules of legislation that prevail in Indonesia as he served. In the Notary Code of Ethics and the Decree of the Minister of Justice and Human Rights of the Republic of Indonesia there is a provision that prohibits a Notary from conducting a form of promotion in social and electronic media, what are the constraints faced by the Notary Supervisory Board in Indonesia? The author examines the problem using normative legal research methods supported by some interviews that are expected to help answer the research and sources interviewed are the parties concerned such as Kaskus, Supervisory Board and also one of Notary in Jakarta. Subsequently, the acts committed by the Notary are clearly violated and appropriate to the sanction imposed on such notary as regulated in Article 6 paragraph (1) of Notary Code and Article 18 Paragraph (4). In this case it is clear that the Notary was found guilty of a form of self-promotion in Social Media, but the Supervisory Board itself essentially oversees the Notary but due to the many obstacles faced by the Supervisory Board, the duties of the Supervisory Board itself do not alter Board regulations Notary Supervisors become more assertive and expected to apply optimally.
\end{abstract}

Keywords :Notary, Code of Ethics 


\section{PENDAHULUAN}

\section{A. Latar Belakang}

Negara Indonesia berdasarkan Pancasila dan Undang-Undang Dasar (UUD) Negara Republik Indonesia 1945 merupakan Negara hukum. Prinsip dari Negara hukum adalah menjamin kepastian, ketertiban dan perlindungan hukum yang berintikan kebenaran dan keadilan. ${ }^{1)}$ Masyarakat sebagai makhluk sosial senantiasa dalam kehidupan sehari- hari akan saling melakukan interaksi sosial. Hubunganhubungan yang terjadi dalam interaksi sosial tersebut tidak jarang merupakan suatu hubungan hukum, yang tentunya akan melahirkan suatu perbuatan hukum, yang mempunyai akibat- akibat hukum tertentu. Dalam konteks inilah, kepastian hukum menjadi dasar dalam pranata sistem hukum suatu negara.

Peran penting dimiliki oleh notaris dalam setiap hubungan hukum kehidupan masyarakat, karena dalam melakukan hubungan hukum tersebut dibutuhkan adanya pembuktian tertulis berupa akta otentik.

Pasal 1 angka 1 Undang-Undang Nomor 2 Tahun 2014 tentang Perubahan Undang-Undang Nomor 30 Tahun 2004 tentang Jabatan Notaris (selanjutnya disebut dengan UUJN) menyatakan bahwa : "Notaris adalah pejabat umum yang berwenang untuk membuat akta dan memiliki kewenangan lainnya sebagaimana dimaksud dalam Undang- Undang ini atau berdasarkan undang-undang lainnya.” Sebagai pejabat umum berarti notaris berwenang untuk membuat suatu akta otentik dan seorang notaris hanya boleh melakukan untuk menjalankan jabatannya di dalam seluruh daerah yang ditentukan baginya dan hanyak di dalam daerah hukum itu ia berwenang.

Perjalanan notaris Indonesia mengalami beberapa perkembangan sesuai dengan perkembangan Negara dan bangsa Indonesia. Sejarah kontemporer Indonesia mencatat bahwa pada era reformasi terjadi perubahan lembaga notariat yang cukup signifikan. Perubahan tersebut ditandai dengan berhasilnya pemerintah orde

\footnotetext{
1) Sjaifurrachman. Habib Adjie, Aspek Pertanggungjawaban Notaris Dalam Pembuatan Akta, (Jakarta: Mandar Maju,2011), hal. 5.
} 
Reformasi mengundangkan Undang-Undang Nomor 30 Tahun 2004 tentang Jabatan Notaris (UUJN). UUJN merupakan pengganti Peraturan.

Notaris dalam melaksanakan profesinya harus memiliki unsur-unsur sebagai berikut :

1. Memiliki integritas yang mantap

2. Harus jujur terhadap klien maupun pada diri sendiri (kejujuran intelektual)

3. Sadar akan batas-batas kewenangannya

4. Tidak semata-mata berdasarkan pertimbangan uang

5. Mempunyai keahlian yang didukung oleh ilmu pengetahuan dan pengalaman yang tinggi ${ }^{2)}$

Dalam pelaksanaan tugasnya, seorang Notaris tunduk serta terikat dengan peraturan perundang-undangan yang berlaku secara umum di Indonesia khususnya peraturan Undang-Undang Nomor 2 Tahun 2014 perubahan atas Undang-Undang Nomor 30 Tahun 2004 tentang jabatan Notaris. Kinerja dari Notaris itu sendiri dibatasi dengan peraturan-peraturan yang berlaku, khususnya Undang-Undang Jabatan Notaris dan Kode Etik Notaris itu sendiri.

Kode Etik Notaris adalah seluruh kaidah moral yang ditentukan oleh Perkumpulan Organisasi Ikatan Notaris Indonesia (INI), dimana berlaku serta wajib ditaati oleh seluruh anggota perkumpulan maupun orang lain yang memangku jabatan Notaris baik dalam pelaksanaan jabatan maupun dalam kehidupan sehari-hari. Notaris sangat perlu untuk mengetahui dan memahami kode etik, di mana mengatur perbuatan-perbuatan apa saja dapat dikatakan sebagai pelanggaran dari kode etik dan sanksi yang dijatuhkan bila melanggar kode etik tersebut. Keberadaan kode etik Notaris merupakan konsekuensi logis dari suatu pekerjaan profesi Notaris. Bahkan ada pendapat yang mengatakan bahwa Notaris sebagai pejabat umum yang diberikan kepercayaan harus berpegang teguh tidak hanya pada peraturan perundang-undangan semata, namun juga pada kode etik profesinya karena tanpa adanya kode etik, harkat

\footnotetext{
2) Abintoro Prakoso, Etika Profesi Hukum, (Surabaya: LaksBang Justitia, 2015), hal. 138.
} 
dan martabat dari profesinya akan hilang. ${ }^{3)}$ Hal tersebut berarti Notaris harus menjaga segala sikap dan perbuatannya serta menjunjung tinggi kewibawaannya dan martabanya sebagai Notaris baik dilakukan dalam jabatannya maupun secara kehidupan sehari-harinya.

Kode etik yang ditetapkan di Banten, pada tanggal 29-30 Mei 2015 yang sebelumnya berlaku Kode Etik Notaris yang ditetapkan pada kongres INI di Bandung tanggal 28 Januari 2005 tersebut memuat kewajiban, larangan dan pengecualian bagi notaris dalam pelaksanaan jabatannya. Notaris dapat dikenakan sanksi apabila terbukti telah melakukan pelanggaran atas ketentuan-ketentuan yang dimuat dalam Kode Etik Notaris.

Hubungan profesi Notaris dengan organisasi Notaris diatur kode etik Notaris, dimana keberadaan kode etik Notaris merupakan konsekuensi dari suatu pekerjaan terkait pelanggaran perilaku para Notaris yang hanya sampai pada sanksi moral. Kode etik Notaris ini memuat unsur kewajiban, larangan, pengecualian dan sanksi yang akan dijatuhkan apabila terbukti Notaris melanggar kode etik. Selain itu kode etik juga mengatur tata cara penegakkan kode etik dan pemecatan sementara sebagai anggota INI. Larangan mengenai kode etik itu sendiri salah satunya adanya perkembangan teknologi.

Sejalan dengan perkembangan teknologi informasi dan komunikasi tentu juga memberikan dampak yang besar bagi para notaris di Indonesia. Tujuan pemanfaatan teknologi informasi dan komunikasi ini salah satunya adalah meningkatkan efektivitas dan efisiensi pelayanan publik. Pemanfaatannya telah menjadi bagian terpenting terutama untuk kapasitas profesi hukum khususnya bagi notaris dalam menjalankan fungsi dan jabatannya sebagai pejabat publik, antara lain digunakan untuk penyebarluasan dokumentasi hukum, informasi hukum, bahkan untuk

\footnotetext{
${ }^{3)}$ Abdul Ghofur Anshori, Lembaga Kenotariatan Indonesia Perspektif Hukum dan Etika, (Yogyakarta: UII Press, 2009), hal. 48.
} 
memecahkan suatu persoalan hukum yang terkait dengan profesi notaris, demi tercapainya keadilan dan kepastian hukum. ${ }^{4)}$

Terdapat beberapa halaman yang dapat digunakan oleh notaris, seperti instagram, blogspot, kaskus, wordpress scribd, multiply, yahoo, facebook, twitter, path dan masih banyak lagi. Banyak kita jumpai notaris yang mempunyai blog maupun laman jejaring sosial lainnya dan mereka juga mencantumkan nama dan jabatannya agar bertujuan menarik perhatian masyarakat. Contohnya saja di kaskus, kaskus merupakan forum diskusi dan jual beli terbesar di Indonesia. Di kaskus mereka dapat mempublikasikan iklan, jurnal, media publikasi bahkan mereka juga menyediakan ruang diskusi dan konsultasi yang akan ditanggapi secara langsung. Hal ini dilakukan agar dapat menarik perhatian masyarakat dan semakin orang yang dapat melihat informasi yang disedikan kaskus tersebut. Tidak sedikit juga notaris yang menggunakan kaskus sebagai tempat untuk mempromosikan dirinya. Hal hal seperti ini sudah jelas melanggar undang undang kode etik notaris yaitu notaris dilarang untuk mempromosikan dirinya baik itu di dalam media cetak maupun elektronik.

Salah satu contoh larangan yang di langgar ini adalah seorang notaris yang berinisial "A" yang mempromosikan dirinya sebagai Notaris termurah di Jakarta Selatan melalui media kaskus. Di dalam website tersebut dicantumkan nama, nomor hp, bahkan memberikan perkiraan harga untuk jasa yang akan di berikan. Juga memberikan jasa konsultasi dan pengantar jemput data yang akan dikerjakan. Juga dijelaskan cara pembayaran yaitu $50 \%$ pada saat penyerahan berkas data, kemudian $25 \%$ pada saat penandatanganan akta dan $25 \%$ pada saat proses selesai. ${ }^{5)}$

\footnotetext{
4) Indonesia Legal Center Publishing, 2014, Suplemen Jabatan Notaris, (Jakarta: Indonesia Legal Center Publishing), hal. 2.

5) A, "Notaris Murah", https://fjb.kaskus.co.id, diakses tanggal 1 Februari 2018.
} 
Hal tersebut jelas melanggar Pasal 4 Ayat (3) Kode etik INI yang berisi Notaris dilarang untuk melalukan publikasi atau promosi diri, baik sendiri maupun secara bersama-sama, dengan mencamtumkan nama dan jabatannya, menggunakan sarana media cetak dan/atau elektronik, dalam bentuk: iklan, ucapan selamat, ucapan belasungkawa, ucapan terima kasih, kegiatan pemasaran, kegiatan sponsor, baik dalam bidang social, keagamaan, maupun olah raga. Demi kepentingan pengawasan dan pelaksanaan dari kode etik INI, dibentuklah Dewan Kehormatan INI yang bertugas untuk memeriksa dan mengambil keputusan atas dugaan pelanggaran ketentuan Kode Etik INI yang bersifat internal atau tidak mempunyai kaitan dengan kepentingan masyarakat secara langsung. ${ }^{6}$

Maka Berdasarkan latar belakang di atas maka tertarik untuk membuat skripsi dengan judul: "PENEGAKAN HUKUM TERHADAP NOTARIS YANG MEMPROMOSIKAN DIRI MELALUI MEDSOS “.

\section{B. Permasalahan}

Berdasarkan uraian latar belakang di atas, maka permaslaahan yang hendak dirumuskan adalah:

1. Bagaimana pelaksanaan pengawasan terhadap pelanggaran kode etik Notaris dalam mempromosikan diri melalui media social?

2. Kendala apa yang mempersulit proses penegakan hukuman jabatan notaris?

\section{Metode Penelitian}

Metode penelitian hukum merupakan suatu proses untuk menemukan aturan hukum, prinsip-prinsip hukum, maupun doktrin-doktrin hukum guna menjawab isu hukum yang akan dihadapi.

\section{Tipe Penelitian}

Tipe yang digunakan dalam penulisan ini yaitu metode penelitian hukum normatif. Menurut Peter Mahmud Marzuki, tidak perlu istilah penelitian hukum

\footnotetext{
${ }^{6)}$ Suhrawardi K. Lubis, 2010, Etika Profesi Hukum, (Jakarta:Sinar Grafika), hal. 35.
} 
normative, karena istilah legal research selalu normatif. Cukup dikemukakan bahwa penelitian ini adalah penelitian hukum, dengan pernyataan demikian sudah jelas bahwa penelitian tersebut bersifat normatife. ${ }^{7)}$ Penelitian hukum dilakukan untuk memecahkan isu hukum yang dihadapi. ${ }^{8)}$ Penelitian hukum (legal research) adalah menemukan kebenaran koherensi, yaitu adakah aturan hukum sesuai dengan prinsip hukum, serta apakah tindakan seseorang sesuai dengan norma hukum atau prinsip hukum.

\section{Jenis dan Sumber Data}

Metode Penelitian normative terdapat 3 (tiga) macam bahan pustaka yang dapat digunakan, yakin:

a. Bahan Hukum Primer

Bahan hukum primer merupakan bahan hukum yang besifat autoritatif, artinya mempunyai otoritas ${ }^{9)}$ bahan hukum primer yang digunakan dalam penulisan ini adalah Undang-Undang 2 Tahun 2014 Tentang Jabatan Notaris.

b. Bahan Hukum Sekunder

Bahan hukum sekunder berupa semua publikasi tentang hukum yang bukan merupakan dokumen-dokumen resmi. ${ }^{10)}$ Bahan hukum sekunder yang digunakan dalam penulisan ini adalah berbagai kepusakaan hukum yakni buku atau jurnal hukum yang berisi mengenai prinsip-prinsip dasar (asas hukum), pandangan para ahli hukum (doktrin) berupa semua publikasi tentang hukum.

\footnotetext{
${ }^{7)}$ Peter Mahmud Marzuki, Penelitian Hukum Edisi Revisi, (Jakarta: Kencana Preneda Media
} Group, 2013), hal. 56.

${ }^{8)}$ Ibid., hal. 60.

${ }^{9)}$ Ibid., hal. 181.

${ }^{10)}$ Ibid., hal 190. 
c. Bahan Non-Hukum

Bahan penulisan yang terdiri atas buku teks bukan hukum yang terkait dengan penelitian, ${ }^{11)}$ seperti Kamus Besar Bahasa Indonesia dan hasil wawancara.

\section{Pendekatan}

Pendekatan skripsi ini, menggunakan pendekatan Undang-Undang dan studi kasus. Pendekatan Undang-Undang adalah pendekatan yang dilakukan dengan menelaah semua Undang-Undang dan regulasi yang bersangkutan paut dengan isu hukum yang sedang ditangani. ${ }^{12)}$ Pendekatan Undang-Undang ini perlu memahami mengenai Jabatan Notaris, serta doktrin-doktrin yang mengacu pada isu hukum yang ditelaah. Studi kasus merupakan suatu studi terhadap kasus tertentu dari berbagai aspek hukum. $^{13)}$

\section{Teknik Pengumpulan dan Pengolahan Data}

Teknik Pengumpulan data yang digunakan dalam penulisan ini adalah dengan studi pustaka terhadap bahan-bahan hukum, baik bahan hukum primer, bahan hukum sekunder dan bahan non-hukum. Penelusuran bahan-bahan hukum tersebut dapat dilakukan dengan membaca, melihat, mendengarkan, maupun melalui media internet. $^{14)}$

Setelah data dan bahan hukum dikumpulkan, tahap selanjutnya adalah melakukan pengolahan data, yaitu mengelola data sedemikian rupa sehingga data dan bahan hukum tersebut tersusun secara runtut dan sistematis. ${ }^{15)}$ Pada penelitian hukum normatif, pengelolaan bahan bertujuan untuk mengadakan sistematis terhadap bahanbahan hukum tertulis dengan cara melakukan seleksi data sekunder dan bahan hukum, kemudian melakukan klarifikasi menurut penggolongan bahan hukum dan menyusun data hasil penelitian tersebut secara sistematis dan logis.

\footnotetext{
11) Mukti Fajar ND dan Yulianto Achmad, Op. Cit., hal. 43.

${ }^{12)}$ Peter Mahmud Marzuki, Op. Cit., hal. 133.

${ }^{13)}$ Ibid., hal.134.

${ }^{14)}$ Mukti Fajar ND dan Yulianto Achmad, Op. Cit., hal.160.

${ }^{15)}$ Peter Mahmud Marzuki, Op. Cit., hal.180.
} 


\section{Tenik Analisa Data}

Hasil pengelolaan data tersebut dianalisis dengan teori yang didapatkan sebelumnya. ${ }^{16)}$ Teknik analisis data yang digunakan dalam penelitian ini adalah penelitian hukum yang bersifat preskriptif. Penelitian preskriptif, akan memberikan argumentasi atas hasil yang diperoleh melalui sumber-sumber penelitian. Argumentasi tersebut berupa penilaian mengenai benar atau salahnya, atau apa yang seyogyanya menurut hukum terhadap fakta atau peristiwa hukum dari hasil penelitian.

\section{PEMBAHASAN}

\section{A. Hasil Penelitian}

\section{Profil KASKUS}

Berdasarkan hasil penelitian terhadap website www.kaskus.com. Kaskus adalah situs forum komunitas maya terbesar Indonesia. Kaskus lahir pada tanggal 6 November 2000 oleh tiga pemuda asal Indonesia yang sedang melanjutkan studi di Seattle, Amerika Serikat. Situs ini dikelola oleh PT. Darta Media Indonesia. Pada bulan Agustus 2005, PC Magazine Indonesia memberikan penghargaan kepada situs Kaskus sebagai situs terbaik dan komunitas terbesar, kemudian Kaskus terpilih kembali sebagai website terbaik pilihan pembaca PC Magazine pada 2006.

Pengawasan Notaris yang dilakukan oleh Majelis Pengawas Notaris (MDP, MPW dan MPP) bahwa pengawasan tersebut tidak hanya pelaksanaan tugas jabatan Notaris agar sesuai dengan ketentuan Undang Undang jabatan Notaris, tetapu juga kode etik Notaris dan tindak tanduk atau perilaku kehidupan Notaris yang dapat mencederai keluhuran martabat jabatan Notaris ( Pasal 67 ayat (5) Undang Undang Jabatan Notaris), hal ini menunjukkan sangat luas ruang lingkup pengawasan yang dilakukan oleh Majelis Pengawas Notaris.

\footnotetext{
${ }^{16)}$ Mukti Fajar ND dan Yulianto Achmad, Op. Cit., hal.183.
} 
Bapak xxxxxx selaku ketua Majelis Pengawas Daerah di xxxxxx berpendapat bahwa pengawasa notaris adalah tindakan pengontrolan terhadap perilaku Notaris dalam menjalankan jabatannya yang mengacu kepada Undang Undang Jabatan Notaris dank ode etik Notaris. ${ }^{17}$

Menurut Bapak xxxx selaku Anggota Majelis Pengawas Daerah di Kabupaten xxxxx menyatakan bahwa pengawasan notaris adalah suatu bentuk tindakan yang dilakukan sebagai sarana control terhadap notaris dalam menjalankan kewajiban serta sebagai saran control untuk tidak melakukan hal hal yang termasuk dalam larangan menurut Undang Undang jabatan Notaris dan Kode etik Notaris. ${ }^{18}$

Hal lain dikemukakan oleh Bapak xxxx berdasarkan hasil wawancara yang menyatakan bahwa pelaksanaan pengawasa Notaris harus disesuaikan dengan kebutuhan dan tujuan yang hendak dicapai melalui kegiiatan tersebut. Dengan demikian langkah langkah yang diambil oleh Majelis Pengawas daerah dalam melakukan pembinaan dan pengawasan haruslah dpikirkan secara cermat dan teliti agar sasaran tepat. Terhadap adanya pelanggaran pemakaian media cetak untuk promosi jabatan notaris dilakukan dengan menerima adanya aduan/laporan yang disampaikan oleh Dewan Kehormatan Daerah. Apabila terdapat adanya aduan/laporan tentang adanya dugaan pelanggaran pemakaian media social untuk promosi jabatan Notaris, maka Majelis Pengawas Daerah melakukan sidang pemeriksaan terhadap Notaris yang bersangkutan.

Pelanggaran pemakaian media online untuk mempromosikan jabatan Notaris adalah pelanggaran yang tergolong kedalam pelanggaran Kode Etik Notaris yang merupakan perbuatan atau tindakan yang dilakukan oleh anggota perkumpulan organisasi Ikatan Notaris Indonesia maupun orang lain yang menjalankan jabatan Notaris yang melanggar ketentuan-ketentuan Kode Etik atau disiplin di dalam organisasi.

\footnotetext{
${ }^{17}$ hasil wawancara

${ }^{18}$ hasil wawancara
} 
Dalam hal tersebut maka Notaris yang menjalankan kewajiban, tugas dan juga wewenangnya mematuhi aturan hukum yang juga berlaku, maka resiko bagi Notaris untuk menghadapi gugatan tersebut akibat dari pelanggaran yang sangat kecil. Bentuk tanggung jawab hukum Notaris adalah dapat berupa tanggung jawab terhadap hukum perdata, hukum pidana, Undang-undang jabatan Notaris dan juga Kode Etik Notaris. Mengenai hal tanggung jawab Notaris selaku pejabat umum yang ada hubungan dengan kebenaran yang materiil, dapat dibedakan menjadi 4 (empat) macam yakni :

a. Tanggung jawab Notaris secara perdata terhadap kebenaran materill terhadap akta yang dibuatnya;

b. Tanggung jawab Notaris secara pidana terhadap kebenaran akta materil yang telah dibuatnya;

c. Tanggung jawab Notaris berdasarkan Undang-undang jabatan Notaris terhadap kebenaran materill dalam akta yang telah dibuatnya;

d. Tanggung jawab Notaris dalam menjalankan tugas jabatan berdasar Kode Etik Notaris yang ada.

Solusi untuk mengatasi pelanggaran tersebut adalah diterapkanya pengawasan terhadap Notaris. Pengawasan Notaris tersebut diharapkan dapat terlaksana dengan baik apabila pihak yang menguasai tersebut adalah yang menguasai dan memahami bidang Notariat.

Majelis Pengawasan Notaris dan Dewan Kehormatan Notaris sebagai penegak Kode Etik Notaris juga memiliki tugas yang cukup berat yaitu mempunyai amanat untuk memastikan agar para Notaris tersebut memahami dan melaksanakan Kode Etik secara konsisten. Selain itu juga ikut memberikan kontribusi kepada eksistensi, kehormatan dan keluhuran profesi jabatan Notaris di dalam masyarakat. Apabila Majelis Pengawas dan Dewan Kehormatan tidak bisa menegakan Kode Etik sesuai dengan adanya perintah yang diamanatkan organisasi makan kredibilitasnya sebagai institusi penegak Kode Etik akan di remehkan oleh para pihak luar.

Hal ini karena secara logis apabila para Notaris telah konsisten melaksanakan Kode Etik makan kecil kemungkinan para Notaris akan tersangkut kasus-kasus yang merugikan sebagian besar masyarakat ${ }^{19}$. Dengan demikian, jika peran Majelis

\footnotetext{
${ }^{19}$ Pengurus Pusat Ikatan Notaris Indonesia, ibid, hal 200
} 
Pengawasan Notaris dari Dewan Kehormatan Notaris telajh mencapai taraf ideal maka dengan sendirinya kualitas Notaris secara umum akan berkala meningkat.

\section{B. Analisa}

\section{Pelaksanaan pengawasan terhadap Notaris yang melakukan promosi diri melalui Media Sosial}

Mengacu pada pengertian Majelis Pengawas menurut Pasal 1 ayat (6) Undangundang jabatan Notaris, yang dirumuskan sebagai berikut: "Majelis Pengawas adalah suatu badan yang mempunyai kewenangan dan kewajiban untuk melaksanakan pembinaan dan pengawasan terhadap Notaris"

Pasal 1 angka 1 peratutan Menteri Hukum dan Hak Asasi Manusia Republik Indonesia Nomor M.02.PR.08.10 Tahun 2004, menegaskan yang dimaksud dengan pengawasan adalah kegiatan yang bersifat preventif dan represif termasuk kegiatan pembinaan yang dilakukan oleh Majelis Pengawas terhadap Notaris.

Dengan demikian ada 3 (tiga) tugas yang dilakukan oleh Majelis Pengawas, yaitu

a. Pengawas preventif;

b. Pengawasan represif;

c. Pembinaan

Pengawasan yang dimaksud meliputi pengawasan terhadap perilaku Notaris diluar pelaksanaan jabatan, berkaitan dengan moral dan perilaku Notaris sebagai pejabat umum yang dipercaya oleh masyarakat sehingga diluar pelaksaan jabatanya sebagai Notaris haruslah tetap menunjukan sikap dan perilaku yang dapat menjaga wibawanya sebagai Notaris atau pejabat umum bagi masyarakat

Majelis Pengawasan dalam melakukan pengawasan perilaku para Notaris yang di luar menjalankan tugas jabatanya sebagai Notaris yang dapat menggangu atau mempengaruhi pelaksanaan tugas jabatan Notaris berpedoman kepada Undangundang jabatan Notaris sehingga memberikan implikasi yang baik dalam pelaksaan tugas jabatan Notaris.

Kewanangan Majelis Pengawas Daerah yang lain adalah melakukan pemeriksaan terhadap Notaris, kewenangan tersebut antara lain menyelanggarakan sidang untuk memriksa adanya dugaan pelanggaran pelaksaaan jabatan Notaris atau 
pelanggaran kode etik Notaris; mengambil keputusan hingga pemberian sanksi kepada Notaris yang melanggar Undang-undang jabatan Notaris dan kode etik Notaris.

Untuk melaksanakan kegiatan pengawasan Majelis Pengawasan Daerah diberikan kewenangan seperti yang dinyatakan pada ketentuan Pasal 70 Undangundang nomor 30 tahun 2004 tentang jabatan Notaris juncto Pasal 13 ayat (2) dan Menteri. Dapat diuraikan kewenangan dari Majelis pengawas Daerah sesuai dengan bunyi Pasal 70 Undang-undang jabatan Notaris, yaitu sebagai berikut.

Majelis Pengawas Daerah berwenang :

1. Menyelenggarakan sidang untuk memeriksa adanya dugaan pelanggaran kode etik Notaris atau pelanggaran jabatan Notaris;

2. Melakukan pemeriksaan terhadap protocol Notaris secara berkala 1 (satu) kali 1 (satu) tahun atau setiap waktu yang dianggap perlu;

3. Memberikan izin cuti untuk waktu sampai dengan 6 (enam) bulan;

4. Menetapkan Notaris pengganti dengan memperhatikan usul Notaris yang bersangkutan;

5. Menentukan tempat penyimpanan protocol Notaris yang pada saat serah terima protokol Notaris telah berumur 25 (dua ouluh lima) tahun atau lebih.

6. Menunjuk Notaris yang akan bertindak sebagai pemgang sementara protokol Notaris yang diangkat sebagai pejabat Negara sebagaimana dimaksud dalam pasal 11 ayat (4);

7. Menerima laporan dari masyarakat mengenai adanya dugaan pelanggaran ketentuan dalam Undang-undang ini;

8. Membuat dan menyampaikan laporan sebagaimana dimaksud pada angka 1 sampai angka 7 kepada Majelis Pengawas Wilayah.

Sedangkan kewenangan dari Majelis Pengawas Daerah menurut Pasal 13 ayat

(4) peraturan Menteri Nomor M.02.PR.08.10 tahun 2004 adalah sebagai berikut :

a. Memberikan izin cuti untuk jangka waktu sampai dengan 6 (enam) bulan;

b. Menetapkan Notaris pengganti

c. Menentukan tempat penyimpanan protokol Notaris yang pada saat serah terima protokol Notaris telah berumur 25 (dua puluh lima) tahun atau lebih;

d. Menerima laporan dari masyarakat mengenai adanya dugaan pelanggaran kode etik Notaris atau pelanggaran ketentuan dalam Undang-undang;

e. Memberi paraf dan menandatangani daftar akta, daftar surat di bawah tangan yang disahkan, dan daftar surat di bawah tangan yang dibukukan yang telah disahkan, yang dibuat pada bulan sebelumnya paling lambat 15 
(lima belas) hari kalender pada bulan berikutnya, yang memuat sekurangkurangnya nomor, tanggal dan judul akta.

Disamping itu berkaitan dengan pengawasan yang dilakukan oleh Majelis Pengawas Daerah hanya berdasarkan adanya laporan dari Dewa Kehormatan. Sebagaimana diketahui dalam Pasal 70 huruf g Undang-undang nomor 30 tahun 2004 tentang jabtan Notaris dan Pasal 13 ayat (4) peraturan Menteri Nomor M.02.PR.08.10 tahun 2004 bahwa menerima laporan dari masyarakat mengenai Undang-undang. Dapat dijelaskan bahwa dalam hal ini tidak adanya peran masyarakat yang ada di Jakarta. Kesadaran dan pengetahuan masyarakat tentang Notaris masih minim sekali dan partisipasi masyarakat dalam penegakan kode etik sangat rendah.

Berkaitan dengan upaya/kegiatan yang dilakukan oleh Majelis Pengwas Daerah Kabupaten Sleman dalam melaksanakan pengawasan terhadap Notaris, yakni melakukan pengawasan yang preventif dan represif, sebagaimana telah dijelaskan sebelumnya . maka berdasarkan ketentuan tersebut, mencoba untuk mengidentifikasi kewenangan-kewenangan mana saja yang termasuk pengawasan yang bersifat preventif dan kewenangan-kewenangan mana saja yang termasuk pengawasan yang bersifat represif.

Keberadaan Majelis Pengawas Notaris Khususnya Majelis Pengawas Daerah sebagai ujung tombak Majelis Pengawas, yang utama adalah untuk melakukan pengawasan terhadap penegakan pelaksanaan jabatan Notaris dan Kode Etik Notaris. Dalam melakukan pengawasan Majelis Pengawas Daerah hrus tanggap dalam menangani pelanggaran yang dilakukan oleh Notaris. Selain itu Majelis Pengawas Daerah juga harus transparan dalam menangani setiap kasus pelanggaran yang terjadi agar kewibawaan dan kapabilitasnya tetap terjaga dimata masyarakat.

Berbicara mengenai pelanggaran-pelanggaran jabatan Notaris atau Pelanggaran Kode Etik Notaris, adapun yang menjadi tolak ukur pelanggaran yang dilakukan oleh Notaris adalah Notaris melakukan tindakan yang dilarang oleh Undang-undang nomor 30 tahun 2004 tentang jabatan Notaris yang tertuang dalam pasal 17 meliputi: 
1. Menjalankan jabtan diluar wilayah jabatanya;

2. Meninggalkan wilayah jabatanya lebih dari 7 (tujuh) hari kerja berturutturut tanpa alasan yang sah;

3. Merangkap jabatan sebagai pegawai negeri;

4. Merangkap jabatan sebagai pejabat negara;

5. Merangkap jabatan sebagai advokat;

6. Merangkap jabatan sebagai pimpinan atau pegawai badan usaha milik Negara, badan usaha milik daerah atau badan usaha milik swasta;

7. Merangkap jabatan sebagai Pejabat Pembuat Akta Tanah di luar wilayah jabatan Notaris;

8. Menjadi Notaris pengganti; atau

9. Melakukan pekerjaan lain yang bertentangan dengan norma agama, kesusilaan, atau kepatutan yang dapat memperngaruhi kehormatan dan martabat jabatan Notaris.

Disamping itu dapat juga dijadikan tolak ukur pelanggaran yaitu berupa tindak tunduk perilaku Notaris yang berada dalam ruang lingkup pengawsan Majelis Pengawas diluar pengawasan tugas pelaksaan jabatan Notaris, dengan batasan;

a. Melakukan perbuatan tercela yang bertentangan dengan norma agama, norma kesusilaan dan norma adat;

b. Melakukan perbuatan yang merendahkan kehormatan dan martabat jabatan Notaris, misalnya berjudi, mabuk, menyalahgunakan narkoba dan berzina.

Terhadap adanya dugaan pelanggaran Notaris, maka Majelis Pengawas wajib melakukan pemeriksaan terhadap Notaris yang bersangkutan. Berdasarkan Peraturan Menteri Nomor M.02.PR.08.10 tahun 2004 urutan pemeriksaan Notaris yang diduga melakukan pelanggaran adalah pasal 23 yaitu adanya laporan tentang dugaan pelanggaran Notaris. Pengajuan laporan dapat berupa:

1. Laporan dapat diajukan oleh pihak yang merasa dirugikan;

2. Laporan harus disampaikan secara tertulis dalam Bahasa Indonesia disertai bukti-bukti yang dapat dipertanggung jawabkan;

3. Laporan tentang adanya dugaan pelanggaran Kode Etik Notaris atau pelanggaran pelaksaan jabatan Notaris disampaikan kepada Majelis Pengawas Daerah;

4. Laporan masyarakat selain sebagaimana dimaksud pada ayat (3) disampaikan kepada Majelis Pengawas Wilayah;

5. Dalam laporan sebagaimana dimaksud pada ayat (3) disampaikan kepada Majelis Pengawas Wilayah, maka Majelis Pengawas Wilayah meneruskan kepada Majelis Pengawas Daerah yang berwenang; 
6. Dalam hal laporan sebagaimana dimaksud pada ayat (3) disampaikan kepada Majelis Pengawas Pusat, maka Majelis Pengawas Pusat meneruskannya kepada Majelis Pengawas Daerah yang berwenang.

Pasal 22 peraturan Mentri Nomor M.02.PR.08.10 tahun 2004 tentang pemanggilan Notaris.

a. Ketua Majelis Pemeriksa melakukan pemanggilan terhadap pelapor dan terlapor.

b. Pemanggilan dilakukan dengan surat oleh secretariat dalam waktu paling lambat 5 (lima) hari kerja sebelum sidang;

c. Dalam keadaan mendesak pemanggilan sebagaimana dimaksud pada ayat 2 (dua) dapat dilakukan melalui faksimili yang segera disusul dengan surat pemanggilan.

d. Dalam hal terlapor telah dipanggil secara sah dan patut yang kedua kali namun. Tetap tidak hadir maka pemeriksaan dilakukan dan putusan diucapkan tanpa kehadiran terlapor.

e. Dalam hal pelapor setelah dipanggil secara sah dan patut tidak hadir, maka dilakukan pemanggilan yang kedua, dan apabila pelapor tetap tidak hadir maka Majelis pemeriksa menyatakan laporan gugur dan tidak dapat diajukan lagi

Pasal 23 Peraturan Menteri Nomor M.02.PR.08.10 tahun 2004 tentang pemerikaan oleh Majelis Pengawas Daerah.

1. Pemeriksaan oleh Majelis Pengawas Daerah tertutup untuk umum;

2. Pemeriksaan dimulai dalam jangka waktu paling lambat 7 (tujuh) hari kalender setelah laporan diterima;

3. Majelis Pemeriksa Daerah harus sudah menyelesaikan pemeriksaan dan menyampaikan hasil pemeriksaan dalam jangka waktu paling lambat 30 (tiga puluh) hari kalender terhitung sejak laporan diterima.

4. Hasil pemeriksaan sebagaimana dimaksud pada ayat (3) dituangkan dalam berita acara pemeriksaan yang ditanda tangani oleh ketua dan sekretaris.

5. Surat pengantar pengiriman berita acara pemeriksaan yang dikirimkan kepada Majelis Pengawas Pusat, dan Pengurus Daerah Ikatan Notaris Indonesia.

Sebagaimana Menteri mempunyai domain pengawasan untuk mengawasi Notaris dalam melaksanakan tugas jabatannya, Ikatan Notaris Indonesia juga mempunyai organisasi yang mengemban fungsi control terlaksananya kode etik di lapangan internal perkumpulan. Organisasi tersebut bernama Dewan Kehormatan. 
Tugas utama Dewan Kehormatan adalah melakukan pengawasn terhadap pelaksanaan Kode Etik Notaris yang telah ditentukan oleh organisasi yang meliputi kewajiban, larangan, dan pengecualian yang harus dilakukan oleh para anggota organisasi.

Dewan kehormatan yang mengemban fungsi Check and Balance pertama kali terhadap sebuah kasus dugaan harus menjadi institusi yang pertama kali mengetahui adanya dugaan pelanggaran Kode Etik yang dilakukan oleh Notaris tertentu seperti promosi jabatan Notaris melalui media cetak. Untuk itu Dewan Kehormatan Daerah harus semakin proaktif dan sensitive dalam melihat permasalahan Notaris di Daerahnya, tidak reaktif menunggu laporan dari masyarakat. Dalam rangka menjalankan tugas dan kewajibannya Dewan Kehormatan Daerah berwenang untuk;

a. Memberikan dan menyampaikan usul dan saran yang ada hubunganya dengan kode etik dan pembinaan rasa kebersamaan profesi (corpsgeest) kepada pengurus daerah

b. Memberikan peringatan, baik secara tertulis maupun lisan secara langsung kepada para anggota di daerah masing-masing yang melakukan pelanggaran atau melakukan perbuatan yang tidak sesuai dengan kode etik atau bertentangan dengan rasa kebersamaan profesi;

c. Memberitahukan tentang pelanggaran tersebut kepada Pengurus Daerah, Pengurus Wilayah, Dewan Kehormatan Wilayah, pengurus Pusat dan Dewan Kehormatan Pusat;

d. Mengusulkan kepada Pengurus Pusat melalui Dewan Kehormatan Wilayah dan Dewan Kehormatan Pusat untuk pemberhentian sementara (schorsing) anggota perkumpulan yang melalukan pelanggaran terhadap kode etik. Dalam menjalankan tugas dan kewajibanya Dewan Kehormatan Daerah dapat mengadakan pertemuan dengan Pengurus Daerah, Pengurus Wilayah, Dewan Kehormatan Wilayah, Pengurus Pusat atau Dewan Kehormatan Pusat. 
Di dalam hal pengawasan, Dewan Kehormatan Daerah dapat mencari fakta pelanggaran atas prakarsa sendiri atau setelah menerima pengaduan secara tertulis dari anggota perkumpulan dengan adanya bukti yang meyakinkan bahwa telah terjadi pelanggaran terhadap kode etik, setelah menemukan fakta-fakta pelanggaran kode etik atau setelah menerima pengaduan, wajib memanggil anggota yang bersangkutan untuk memastikan apakah betul telah terjadi pelanggaran dan memberikan kesempatan kepadanya untuk memberikan penjelasan dan pembelaan. Hal ini dilakukan karena Dewan Kehormatan Daerah berinteraksi langsung dengan Notaris dan pihak yang mengetahui duduk perkara pelanggaran kode etik untuk pertama kalinya.

Tolak ukur pelanggaran berdasarkan Pasal 4 Ayat (3) kode etik Notaris menyatakan, Notaris dan orang lain yang menmangku dan menjalankan jebatan Notaris dilarang melakukan publikasi atau promosi diri, baik sendiri maupun secara bersama-sama, dengan mencantumkan nama dan jabatanya menggunakan sarana media cetak dan/atau elektonik, dalam bentuk:

1. Iklan;

2. Ucapan Selamat;

3. Ucapan Belasungkawa;

4. Ucapan Terimakasih;

5. Kegiatan Pemasaran;

6. Kegiatan sponsor, baik dalam bidang sosial, keagamaan, maupun olahraga.

Terhadap suatu larangan yang terdapat pada Pasal 4 ayat (3) Kode Etik Notaris, terdapat pula pengecualianya. Pasal 5 Kode Etik Notaris mengatur pengecualian tersebut karena di anggap tidak termasuk suatu pelanggaran kode etik, yaitu diantaranya: "memberikan ucapan selamat, ucapan berduka cita dengan mempergunakan kartu ucapan, surat, karangan bunga ataupun media lainya dengan tidak mecantumkan Notaris, tetapi hanya nama saja". Selain itu juga yang tidak termasuk pelanggaran adalah pembuatan namadan alamat Notaris dalam buu panduan nomor telepon, fax yang diterbitkan resmi PT. Telkom atau lembaga resmi; memasang penunjuk jalan dengan ukuran yang tidak melebihi $20 \mathrm{~cm}$ x $50 \mathrm{~cm}$ dasar 
warna putih, tulisan hitam tanpa mencantumkan nama Notaris tersebut, dipasang dengan radius maksimal 100 meter dari kantor Notaris.

Sebagai pejabat umum yang memiliki fungsi melayani masyarakat, Notaris sudah selayaknya tidak boleh melakukan kegiatan-kegiatan yang bertujuan mencari keuntungan, termasuk diantaranya memasarkan jasa.

Selain hal itu juga adanya melakukan pengawasan, Dewan Kehormatan Daerah dalam melaksanakan tugasnya tersebut juga melakukan pemeriksaan terhadap anggota organisasi yang diduga melakukan pelanggaran atas Kode Etik.

Berdasarkan Pasal 1 ayat (8) bagian a Dewan Kehormatan mengambil keputusan atas dugaan pelanggaran ketentuan Kode Etik yang sifatnya internal atau yang tidak mempunyai kaitan dengan kepentingan masyarakat secara langsung ${ }^{20}$. Dasarnya pada perihal mengenai tata cara pemeriksaan juga menjatuhkan sanksi diatur dalam Bab V Pasal 8 Kode Etik. Sesuai pelaksanaanya pengawasan Kode Etik Melalui proses pemeriksaan di Dewan Kehormatan Daerah atas dugaan Pengurus Daerah Ikatan Notaris Indonesia Maupun laporan dari pihak lain, yang juga dalam jangka waktu 7 (tujuh) hari kerja sejak di adakanya hal tersebut akan dilakukan pemeriksaan. Jika terdapat dugaan yang cukup kuat maka Dewan Kehormatan Daerah memanggil Notaris yang ada kaitanya melalui surat untuk mendengarkan keterangan dan diberi kesempatan untuk pemanggilan ketiga Notaris tersebut tidak hadir maka Dewan Kehormatan akan tetap melaksanakan sidang pemeriksaan untuk membicarakan pelanggaran yang dilakukan oleh Notaris tersebut.

Dalam menangani atau menyelesaikan suatu perkara, para Anggota Dewan Kehormatan Daerah harus :

a. Tetap menghormati dan menjunjung tinggi martabat anggota yang bersangkutan;

b. Selalu menjaga suasana kekeluargaan;

c. Merahasiakan segala apa yang ditemukanya.

${ }^{20}$ Pasal 1 ayat (8) bagian a Kode Etik Ikatan Notaris Indonesia 


\section{Kendala yang mempersulit proses penegakan kode etik Notaris}

Aturan yang termuat dalam Kode Etik terkadang tidak diindahkan. Pengabdian Kode Etik Notaris selalu disebabkan adanya pengaruh negated sebagai salah satu individu dalam masyarakat maupun dalam hubungan kerja yang ada di dalam organisasi profesi. Secara internal yakin dalam diri yang individu Notaris itu sendiri mungkin juga dapat dikarenakan sifat manusia nya, misalnya sifat konsumerisme atau nilai yang di perolehnya dalam menjalankan profesi sebagai seorang Notaris. Sedangkan factor eksternal mungkin dikarenakan lingkungan budaya yang melingkupi Notaris ${ }^{21}$.

Penerapan sanksi sangat penting dalam rangka untuk mewujudkan profesionalisme, oleh karena itu ketika sanksi-sanksi yang telah ada dan belum memberikan kontribusi besar terhadap peningkatan profesionalisme kerja Notaris, maka sudah seharusnya adanya sanksi tambahan yang diberlakukanya yang tentunya juga telebih dahulu di sepakati oleh sesame Notaris yaitu sanksi berupa denda, karena sanksi denda tentu memberikan juga efek secara langsung ketika salah satu seorang Notaris melakukan pelanggaran terkait Kode Etik Notaris. ${ }^{22}$

Disamping itu diperlukan adanya penindakan. Tndakan tersebut meliputi:

a. Teguran himbauan supaya menghentikan pelanggaran, dan jangan melakukan pelanggaran lagi;

b. Mengucilkan pelanggaran dari beberapa kelompok profesi sebagai orang yang tidak disenangi sapai menyadari kembali perbuatanya;

c. Memberlakukan tindakan hukum berupa Undang-undang dengan sanksi nya yang keras.

Urgensi sanksi Kode Etik sangat penting dalam rangka terwujudnya profesinalism Notaris karena di dalam kerangka efektifnya peraturan yang di perlukan adanya berupa sanksi, sebab sanksi akan juga memberikan efek memaksa dan jera pula terhadap pihak yang melakukan pelanggaran. Dengan demikian juga dikatakan bahwa setiap peraturan yang memiliki sifat memaksa sebagai suatu bentuk

\footnotetext{
${ }^{21}$ Abdul Ghofur Anshori, Op.cit, hlm 168

22 Syihan et.al, pelaksanaan Kode Etik Dalam Menjalankan Jabatan Notaris,pasca.unhas.ac.id/jurnal/files
} 
upaya perlindungan hukum, hanya saja pihak yang terkait di dalam penegakan Kode Etik Notaris tidak menjalankan serta juga tidak menerapkan secara efektif penjatuhan sanksi bagi Notaris yang telah melakukan pelanggaran Kode Etik Notaris.

Disamping itu Dewan Kehormatan dalam melaksanakan fungsi dan kewenanganya yang bersifat aktif dan juga pasif seperti yang diamankan oleh organisasi Ikatan Notaris Indonesia. Bersifat aktif maksudnya Dewan Kehormatan harus proaktif turun ke lapangan melakukan pengawasan terhadap Notaris yang sudah teridentifikasi melakukan pelanggaran Kode Etik, maka Dewan Kehormatan dapat juga menindak lanjuti dengan melakukan pemanggilan terhadap Notaris tersebut pula. Sedangkan kewenangan yang bersifat pasif yaitu Dewan Kehormatan hanya menerima berupa laporan dari masyarakat terkait adanya dugaan pelanggaran dari pihak Notaris.

Tidak optimalnya kinerja dari Dewan Kehormatan dalam menjalankan tugas dan kewenanganya karena tidak adanya suatu bentuk SOP (Standart of Procedur). SOP ini penting dalam rangka sebagai penegasan dalam melakukan suatu fungsifungsi serta kewenangan yang dimiliki Dewan Kehormatan. SOP diperlukan sebagai dasar pemeriksaan yang bersifat subjektif dan juga penentuan keputusan oleh sang Dewan Kehormatan atas pelanggaran tersebut.

Disamping itu juga menurut Sidharta Pohan Prastowo, belum efektifnya Institusi Dewan Kehormatan yang merupakan alat perlengkapan organisasi dari suatu profesi yang juga ditegaskan dalam suatu penelitian menyimpulkan bahwa adanya beberapa factor penyebab kritik dan keluhan terhadap kualitas pelaksanaan profesi hukum di Indonesia. Beberapa hal yang menjadi penyebab utama dari rendahnya kualitas pengembangan profesi hukum adalah:

1. Tidak berjalannya control dan pengawasan dari masyarakat;

2. Organisasi profesi tidak dilengkapi dengan sarana dan mekanisme bagi masyarakat untuk menyampaikan keluhan;

3. Rendahnya pengetahuan masyarakat mengenai substansi Kode Etik Profesi hukum karena buruknya upaya sosialisasi dari pihak profesi sendiri; 
4. Belum terbentuknya kultur dan kesadaran dari para pengemban profesi hukum untuk menjaga martabat luhur profesinya;

5. Tidak adanya kesadaran etis dan moralitas diantara para pengemban profesi, bahwa mentaati keputusan Dewan kehormatan Profesi merupakan salah satu factor dalam menjaga martabat profesi. ${ }^{23}$

Lebih lanjut Sidharta Pohan Prastowo mengatakan bahwa penegakan Kode Etik Notaris adanya terkena hambatan karena Dewa Kehormatan tidak tanggap dalam menangani pelanggara Kode Etik Notaris ${ }^{24}$. Hal lain juga dianggap menjadi suatu hal yang buruk dalam suatu gerakan penegakan Kode Etik Notaris adalah sifat yang saling melindungi anar teman yang tidak dilakukan nya dalam proporsi yang benar. Mengingat banyaknya pelanggaran Kode Etik yang ada maka menuntut agar peranan Dewan Kehormatan lebih ditingkatkan dalam hal menjalankan fungus pengawasan dan penegakan Kode Etik Notaris, dengan cara mengambil tindakan tegas pada setiap pelanggaran Kode Etik yang menjadi kewenangan Dewan Kehormatan, menjatuhkan sanksi setimpal pada setiap pelanggaran yang dilakukan, juga adanya transparansi dalam menjatuhkan sanksi terhadap pelanggaran dan konsisten dari sanksi yang dijatuhkan antar satu kasus dengan kasus lainya.

Suatu upaya penegakan Kode Etik adalah salah satu cara guna melestarikan nilai-nilai luhur, sehingga di dalam pelaksanaannya profesi Notaris tidak mengalami kemerosotan moral tetapi memperoleh peningkatan kualitas kemuliaan dari profesi tersebut.

\footnotetext{
${ }^{23}$ Sidaharta Pohan Prastowo, 2002, standar Disiplin Profesi Hukum, Legal Research Institut, Bandung , hlm 2-3

${ }^{24}$ Sidharta Pohan Prastowo, ibid, hlm 59.
} 


\section{PENUTUP}

\section{A. Kesimpulan}

Pada Jurnal ini maka dapat mengemukakan kesimpulan yang di dapat dari permasalahan yang terdapat dalam skripsi yang berjudul "Penegakan Hukum Terhadap Notaris Yang Mempromosikan Diri Melalui Media Sosial”. Dalam hal ini dapat mengambil sebuah kesimpulan bahwa di dalam permasalahan ini bahwa pada dasarnya dengan adanya suatu bentuk pengawasan terhadap Notaris yang ada sebenarnya telah banyak juga membantu nilai kesucian di dalam profesi tersebut, namun pengawasan serta fungsi yang telah di berikan kepada pengawas belum lah sempurna masih butuh banyak nya perbaikan atau bisa kita sebut pengawasan yang belum kuat, lemahnya pengawasan tersebut juga di karenakan kendala kendala yang terjadi di dalam lingkup pengawasan dan juga Notaris itu sendiri.

\section{B. Saran}

Dari kesimpulan yang telah ditulis, maka dalam kesempatan kali ini ingin memberikan saran dalam penyelesaian permasalahan ini sebagai berikut:

1. Ada baiknya sebuah profesi yang telah memilik tanggung jawab yang berat lebih baik agar penyeleksian atau penyaringan untuk dapat menjabat sebagai profesi tersebut harus lebih di perketat atau lebih di signifikasi syarat dan ketentuan dalam mengemban profesi tersebut.

2. Ada baiknya pula sistem di dalam pengawasan untuk pengemban profesi ini lebih di perbaiki dan juga lebih di perdalam sistem pengawasanya tersebut, di karena kan pula begitu banyak kendala yang di hadapi maka sistem pengawasan harus lebih di tingkatkan lagi dengan guna agar fungsi dari adanya badan pengawasan profesi tersebut menjadi berguna secara optimal dan juga maximal.

\section{DAFTAR PUSTAKA}

Sjaifurrachman, Habib Adjie. Aspek Pertanggung Jawaban Notaris dalam Pembuatan Akta. Jakarta: Mandar Maju,2011 
Prakoso, Abintaro. Etika Profesi Hukum. Surabaya: LaksBang Justitia, 2015

Anshori, Abdul Ghofur. Lembaga Kenotariatan Indonesia Perspektif Hukum dan Etika. Yogyakarta: UII Press, 2009

Legal Center Publishing, Indonesia. Suplemen Jabatan Notaris. Jakarta: Legal Center Publishing, 2014

"Notaris Murah”. https://fjb.kaskus.co.id. Diakses tanggal 1 Febuari 2018

K. Lubis, Suhrawardi. Etika Profesi Hukum. Jakarta: Sinar Grafika, 2010

Abdulkadih, Muhammad. Etika Profesi Hukum. Bandung: PT. Citra Aditya Bakti, 2001

Notodisoerojo, R. Soegono. Hukum Notariat di Indonesia Suatu Penjelasan. Jakarta:

CV Rajawali, 1982

Sulihandri hartanti dan Nisya Rifiani. Prinsip-Prinsip Dasar Profesi Notaris. Jakarta: Dunia Cerdas, 2013

M. Hadjon, Philipus. Pengantar Hukum Perjanjian. Surabaya: Yuridika, 1993

Basah, Sjachran. Pencabutan Izin Sebagai Salah Satu Sanksi Hukum Administrasi Negara. Surabaya: FH UNAIR, 1995

Adisapoetra, R.Kosim. Pengantar Ilmu Hukum Administrasi Negara. Jakarta: Pradnya Paramita, 1978

HR, Ridwan. Hukum Administrasi Negara. Jakarta: PT Raja Grafindo, 2013

Nurmayani. Hukum Administrasi Daerah. Lampung: Universitas Bandar Lampung, 2009

Kantaprawira Rusadi. “Hukum dan Kekuasaan”, Yogyakarta, 1998

Sastradipoera, Komarudin. Manajemen Marketing Suatu Pendekatan. Bandung: Kappa Sigma, 2003

Morissan. Komunikasi Pemasaran Terpadu. Jakarta: Kencana, 2010

Mahmud Marzuki, Peter. Penelitian Hukum. Jakarta: Kencana Preneda Media Group, 2013

Syihan. "Pelaksanaan Kode Etik Dalam Menjalankan Jabatan Notaris”, Makassar: UNHAS 
Pohan Prastowo, Sidharta. Standar Disiplin Profesi Hukum. Bandung: Legal Research Institut, 2002

Indonesia. Undang-undang Nomor 2 Tahun 2014 tentang Jabatan Notaris (Lembaran Negara Republik Indonesia Tahun 2014 Nomor 3, Tambahan Lembaran Negara Republik Indonesia Nomor 5491). 